\title{
Montage in the Contemporary Russia Female Literature
}

\author{
$\mathrm{Li} \mathrm{Li}$ \\ Northwest Normal University \\ Lanzhou, China 730070
}

\begin{abstract}
Montage, as a rhetorical device and discourse construction, plays a very important role in the discourse, such as the means of inserting the plot and building artistic image, and the basis for controlling the rhythm of the text. Montage is not only a means of subjectivism in narration, but also a means of cognitive discourse. By changing the lens of narration, multilevel and multi perspective transformation of the text can be achieved.
\end{abstract}

Keywords-Montage; subjectivism in narration; multi perspective; discourse construction

\section{INTRODUCTION}

The word "Montage" was created and established in the early stage of the development of film art. This term was first put forward by Eisenstein, which refers that to edit the scenes occured at different places and different times into a complete word according to the certain order. "Montage", as a rhetorical device, has been used for a long time. However, the meaning has changed after it was used in philology that means "the constraction mode of those literary works that characterized by internittent (discrete) and fragmented description. It also tends to express certain contrastive and antagonistic relationships, which are not subject to the logical restriction of the description object, and directly represent the author's ideological process and association." Montage plays a very important role in the discourse, such as the means of inserting the plot and building artistic image, and the basis for controlling the rhythm of the text. Montage can vividly show the essential connections between various phenomena that cannot be directly observed, and help to grasp the heterogeneity and richness, contradiction and unity of the world. ${ }^{2}$

Montage was first put forward as a structural means of subjectivism in narration by Okin Geoff. He believed that montage is a structural means to describe subjectivist construction. It can make discourse more hierarchical and multi perspective, and it can better reflect the author's personal style. The application of montage can demonstrate the character's point of view and consciousness, and realize the objective narration of the author to the subjective expression of

Written by W.A.Halizev, Translated by Zhou Qichao. An introduction to Literature [M]. Beijing: Peking University Press, 2006. 341. Written by W.A.Halizev, Translated by Zhou Qichao. An introduction to Literature [M]. Beijing: Peking University Press, 2006. 343. the character's heart through the alternation of narration angle. Or using the eyes of people to dynamically present the development process of things, and thus affect the reader by the changes of the lens at last. Montage is a means to construct a text, and also a means of discouse cognition.

The essence of montage lies in the effect and character that produced after the integration and reconstruction of materials, which is editing and combination in short. Montage is a narrative method commonly used, often called narrative montage, characterized by plot presenting and event demonstration as the theme, and divides the combination in accordance with the time flow and the causality of the plot. Narrative montage contains the following forms, such as parallel montage, cross montage, continuous montage and so on. Okin Geoff believes that there are two kinds of montage that are closely related to the subjectivism of narration, cross montage and continuous montage. ${ }^{3}$ In Contemporary Russian women's literature, the author often uses montage methods that full of expressive force to edit and combine the plots, so as to break the limitation of time and space of the narration and enhance the artistic aesthetic effect of texts.

\section{CONTINUOUS MONTAGE}

Continuous montage is the most commonly and widely used narrative method in narrative montage. Different from the multithreading development of parallel montage, continuous montage continully narrate rhythmically according to the logical sequence of event along a single thread, which is natural, simple and smooth and gives the reader a strong sense of lens that constantly changing. As said by Горшков, continuous montage is based on the complete coincidence with the sight of the character, and is in constant movement and change. This kind of description not only can reflect the displacement and changing of the scene, but also reflect the movement of the character itself and the change of the character's angle of view. 4 In

V.V. Odintsov. Stylistics of the text / Otv.red.A. Gorshkov, izd.5-e. [M]. M: The book house "Librocom", 2010. (В.В.Одинцов. Стилистика текста / Отв.ред.А.И.Горшков, изд.5-е.[М]. М:Книжный дом «Либроком», 2010).

V.V. Odintsov. Stylistics of the text / Otv.red.A. Gorshkov, izd.5-e. [M]. M: The book house "Librocom", 2010. (В.В.Одинцов. Стилистика текста / Отв.ред.А.И.Горшков, изд.5-е.[М]. М:Книжный дом «Либроком», 2010) 
ЛюдмилаСтефановнаПетрушевская's "The Music of the Hell", the author frequently used montage.

\section{Example 1:}

Ночь переночевали в общежитии дальнего совхоза под дивной картиной с моряком и девушкой в лодке, на картине стоял уютный розовый закат, за рекой черной полосой лежал какой-то лесной массив, и весь глупый студенческий народ приходил смеяться над этой картиной, а Нине было так хорошо под ней, даже хотелось украсть ее. На картине был вечерний покой и царила гармония, а вокруг в голых окнах виднелась грязь до горизонта со вкраплениями проржавевшей техники и каких-то прошлогодних незапаханных кустов репейника. Жить в этом общежитии было нельзя, среди металлических кроватей и стен, выкрашенных серо-зеленой масляной краской, частично облупившейся как раз над картиной. Наивный пейзаж наивно прикрывал протечку на стене, в этом был первый след разумной деятельности человека по украшению безобразия. («Музыка ада»)

This paragraph was set in two scenes, one was the picture on the wall of the dormitory of state farm, and another was the interior of the dorm of the state-owned farm, which clearly reproduced Nina's vision and the changing perspective. The first scene one can see was a wonderful picture on the wall that a sailor was rowing with her beloved girl on the river in the light of the sunset. On the bank of the river was a large green and orderly planted forest, which is serene, harmonious and in peace. Nina loved this so much that she even wanted to steal it. The next scene was the shabby dorm in the reality, full of dirt, rusty machine, iron bed and iron wall that coated with gray green paint everywhere. Even the paint above the picture is falling off. Nina felt unable to live in the dorm. This is similar to the contrastive description in literature, which is that through the strong constrast of lens and the scene in the contents (such as rich and poor, pleasure and pain, life and death, noble and humble, success and failure etc.) and form (such as scene size, cold or warm colors, sound intensity, moving and motionlessness etc.), the effect of conflict is produced to express the implied meaning of the author or to strengthen the content and thought of the author. Through continuous montage, the author described two scenes that were totally different through visual displacement and perception of the character. The scenes depicted seemed to have no direct correlation, but they all served the author's narrative purpose, and reflected the emotions and thoughts of the character on the other side. The novel delivered the misery and meaningless of life, the despair to the real life, the confusion and embarrassment toward the existence of life. In the eyes of the hero, the real life seemed more pain and helplessness in contrast to the magnificent picture. In the author's objective narration, the application of continuous montage made the perspective of characters change among different scenes, and made the objective narration of the writer fresh and vivid.

\section{Example 2:}

Инну посадили за стол возле окна на шесть человек. Против неё сидела старушка с розовой лысинкой, в прошлом клоун, и замужняя пара: он - по виду завязавший алкоголик. У него были неровные зубы, поэтому неровный язык, как хребет звероящера, и привычка облизываться. Она постоянно улыбалась хотела понравиться Инне, чтобы та, не дай бог, не украла её счастье в виде завязавшего алкоголика с ребристым языком. Одета была как чучело, будто вышла не в столовую высокопоставленного санатория, а собралась в турпоход по болотистой местности.(«Старая собака»)

This is a paragragh from "An old Dog" of Vitokaleva. The novel tells the story of the heroine Inna, who paid for a recuperation card and went to a nursing home to find a highpaying husband who was not older than 82 . In this part, the vision of Inna and the changing angle of view were presented. First she saw the inside of the restaurant. When she walked into the restaurant, looking around the hall, she found it looks like a branch of the nursing home and old was showed in various forms. She estimated that 101 years old here is middle age. She was regret that she had wasted her holiday, her travel expenses, and the money for her recuperation. Then the angle was switched to a dining table for six by the window in the restaurant. Opposite Inna sat a bald old lady with a pink glance over her head. There was a couple, of which the man has a sullen complexion and cold attitude, lacking of interest in life and passionless, and obviously overdrunked, and the woman was dressed in a strange way, as if she didn't come to the restaurant to eat, but to go hiking. This section adopted the typical montage method, which created a huge contrast through the switch of the character lens, resulting in a strong contrast effect that she has come to this place at such a cost that she felt lost, helpless, and speechless. She wanted to find her fiance, but the man sitting next to her was so unsightly that there was no hope. The use of montage has strengthened the tragic color of the novel, enriched the inner activities of the characters, and promoted the redevelopment of the novel plot. At the same time, the use of montage method showed difficult and helpless life of the character that she even began to question the value and significance of life, thinking about whether people can have pursuit or realize the dream, and whether to firmly believe that the meaning of living in despair. This kind of scence wouldl guide the reader's attention, arouse the reader's imagination and thinking.

\section{CROSS MONTAGE}

The cross montage, also called alternating montage, alternates and splits together two or several plots occurring at the same time and different regions. The development of one clue often affects several other clues, and each clue is interdependent and finally converged. This editing technique is very easy to create suspense, forming a tense and intense atmosphere, and strengthening the sharpness of the conflict, which is an effective way to control the readers' emotions.

In Tolstoy's "Hunting mammoths", the heroine Zoya wanted to find an ideal mate, but her fiancé Vladimir was not so desirable in all aspects. So the author's narration was centered on the description of the disharmony between Zoya and Vladimir. For example, she hoped that her fiancé's household items, including toothbrushes, razors and clothes, would be "in her house", but instead, "he hasn't left any trace." She hoped that Vladimir were a surgeon, since she worked in a hospital, it would be "easy to fit into the magical world of 
medicine", and she hoped to "fall into the blood of the surgeon". She wanted to travel to Caucasus in summer, enjoying the sunshine and wine, but Vladimir dragged a canoe home and brought two colleagues, so that she had to raise her legs in a crowded room. Zoya had to go hiking with her fiancé and his friends. She had to endure the rough and tumble wind and the cold, and the odour from Vladimir like the dog's hair, which made her extremely uncomfortable and unable to adapt to. Instead, Vladimir enjoyed the life very much, happily "eating the canned pea lunch", getting up early every day, and so on. The whole novel was the crossing frame of Zoya and Vladimir. The contrast of the two lens reflected different opinions toward life, which brought about the emotional collision, and with the stimulated emotion, the reader was able to empathize with the thoughts expressed by the author. In this way, the reader is involuntarily immersed in the process, willing to go along with this idea. In the author's narration, the description of these things is objective, just a simple list, but the intersected things are the choice of the main body, implying the emotional change of the characters and revealing the inner world of the characters. Cross montage destroys the objectivity of narration and endows the narration with the characteristics of subjectivity. It is the use of this kind of montage narration that makes Tolstoy break the traditional pattern of love and marriage, "reverse the role of women in a relationship from "prey" to a "hunters", from the gentler partner to the powerful part who manipulates the male, while the male becomes the female's hunting target and taming object". 5

In Tolstoy's short story "Dear Shura", the heroine Alexandra Ernestofuna communicated with the narrator about her life. She has gone through three marriages and a love affair. When it comes to this legendary life, the text has been interspersed with two actions: look at the photos and drink tea and snacks. For each period of life, the heroine would show photos of that period, and then told her stories and experiences, accompanied with recalls, sigh and regret, etc. and sighing from time to time. While telling about her stories, she would urge the narrator to drink tea and taste the dessert, and let the narrator taste her jam, which made he praised a lot on her tea, dessert and jam. This kind of narration is of typical cross montage. In the process of talking and drinking tea, the narration run through history and the present through looking photos and listening to her life experiences and perceptions, sigh on the past and praise tea and dessert at present. Thus, the author made up the whole text with one and another shot. This made the story more smooth, vivid and infectious, greatly aroused the reader's association, imagination and interest, and enabled the reader to perceive each detail of the text more clearly and comprehend the thoughts and ideas of the text. Texts often carry with information. Besides the literal meaning the texts carried, the author also wants to convey his opinions, attitude and viewpoint toward the events, characters and phenomena he described, and thus reflect the author's understanding and perception of society and life. The information are not floating on the surface of the text, but needs to be understood by the reader, which is precisely the

Chen Fang. Research on Contemporary Russian Female Novels [M]. Beijing: Renmin University of China Publishing house, 2007. 97. author's intention of creation, the embodiment of the author's philosophy and world view. The richer the reader's knowledge system, the stronger the discourse analysis ability and the more specific the grasp of the implied information are. The use of montage can easily transform the narrative angle from the author's objective narration to the subjective expression of the character. Without this cross, the narration of the text would be dull and unwieldy. The use of montage can influence the psychological rhythm of readers through the change of lens, presenting a special way of thinking -- montage thinking mode.

\section{CONCLUSION}

Montage is not only a means of describing subjectivity, but also a means of cognitive discourse and a means of discourse construction. Through the changing of narrative lens, the multi-level and multi-angle transformation can be realized.

\section{REFERENCES}

[1] V.V.Odintsov. Stylistics of the text [M]. Moscow: Ursus, 2004 (В.В.Одинцов. Стилистика текста[М].Москва: Урсс, 2004.)

[2] LR Rabdanov. Subjective narrative as a component of the language composition of the text. Scientific notes of the Transbaikal State Humanitarian and Pedagogical University named after NG Chernyshevsky [С]. 2011. (Л.Р.Рабданова. Субъективированное повествование как компонент языковой композиции текста. Ученые записки Забайкальского государственного гуманитарнопедагогического университета им.Н.Г.Чернышевского[С]. 2011.)

[3] E.E. Anisimov. Linguistics of the text and intercultural communication: a textbook for students of the Faculty of Science and Information [M]. M.: Asademia, 2003. с.128. (Е.Е.Анисимов.Лингвистика текста и межкультурная коммуникация :учеб.пособие для студ.факт.иностр.яз.вузов[M]. М.:Academia, 2003. с.128.)

[4] A.V. Ivanov. Subjectification of the narration (on the material of Vladimir Makanin's prose) [D]. Chita, 2008. p.144-146. (А.В.Иванова. Субъективация повествования ( на материале прозы Владимира Маканина )[D].Чита, 2008. с.144-146.)

[5] K.V. Klimenko. Installation techniques of language composition in compositions in autobiographical texts by Yu.M.Nagibin, Philological Sciences. Issues of theory and practice Tambov: Diploma, 2013. No. 5 (23): in 2 hours Part II. C. 101-106. (К.В.Клименко.Монтажные приемы языковой композиции в композиции в автобиографических текстах Ю.М.Нагибина, Филологические науки. Вопросы теории и практики Тамбов: Грамота, 2013. № 5 (23): в 2-х ч. Ч. II. С. 101-106.)

[6] Zhang Bing. Defamiliarization and Montage: A Review on Russia Formalistic Film [J]. Russian Literature, 2013, (2): 144-150. 